\author{
Mirosław Karpiuk \\ University of Warmia and Mazury in Olsztyn \\ ORCID: 0000-0001-7012-8999 \\ miroslaw.karpiuk@uwm.edu.pl
}

\title{
Position of the Local Government of Commune Level in the Space of Security and Public Order
}

\author{
Miejsce samorządu gminnego w przestrzeni bezpieczeństwa \\ i porządku publicznego
}

\begin{abstract}
SUMMARY
The paper addresses problems of the position of the local government of the commune level in the space of security and public order. The commune pursues tasks in this area besides other public tasks and ensuring security and public order falls within the category of fundamental tasks, the fulfilment of which requires considerable effort, including financial effort. The commune as a basic unit of local government is to respond to threats most immediately and neutralise them with its own resources and means, or if this is not possible, to prevent them from spreading. This is the main objective of the commune to be pursued in this area of running public administration.
\end{abstract}

Keywords: commune; security; public order

\section{INTRODUCTION}

Security and public order tasks are carried out by public administration entities of various levels. The legislature has assigned powers in this area both to the central government administration operating in regions and nation-wide, as well as to the local government acting in the area of a commune (gmina), county (poviat) and province (voivodeship, województwo). Thus, it can be concluded that the jurisdiction of the administration competent for security and public order extends to both the whole state and the local and regional areas. This classification arises out of the need to match the tasks and their scope not only to the forms of public management applied within the state, but also to the need to ensure security and 
public order, the quality and availability of services being provided, or optimise costs of their implementation.

Ensuring security is ranked high in the catalogue of social needs. It can even be said that this is one of the basic human needs to ensure one's undisturbed existence. Likewise, public order is the institution which guarantees the proper development of society and the proper functioning of the state apparatus and local government.

The local government of the municipal level plays a crucial role in the space of security and public order, which is reflected in the social perception of public institutions, including trust in them. How it will cope with the implementation of these public tasks depends not only on the financial resources but also on the security policy that the local authorities adopt and their commitment to securing societal needs in this respect.

\section{NATURE OF MUNICIPAL GOVERNMENT}

The municipal-level local government is one of three tiers of local government (next to county government and provincial government). The commune has been established in public life as a form of decentralised administration to manage local affairs. It performs basic tasks, including those of security and public order, which are tailored to its capabilities as the structure closest to citizens.

The legislature states that the territorial system of the Republic of Poland assumes the decentralisation of public authority and that the fundamental territorial divisions of the State are to take account of social, economic or cultural ties while ensuring the territorial units the capacity to perform public duties ${ }^{1}$. As part of such fundamental territorial divisions of public administration (including security and public order administration), the commune was distinguished as a unit best acquainted with the needs of its inhabitants.

According to the fundamental principle of decentralisation included in Article 15 (1) of the Polish Constitution, the local government carries out only the tasks conferred on it by statutes and does not have the right to assign public tasks to itself. The commune's tasks shall always be fulfilled within the statutory frame-

1 Article 15 of the Constitution of the Republic of Poland of 2 April 1997 (Journal of Laws No. 78, item 483 as amended), hereinafter: the Polish Constitution. English translation of the Constitution at: www.sejm.gov.pl/prawo/konst/angielski/kon1.htm [access: 10.03.2019]. Decentralisation of public authority does not necessarily imply its exclusive powers in all aspects of the state's territorial regime and the inadmissibility of the functioning of certain centralised structures where required due to the specificity of the tasks to be performed. See P. Sarnecki, [in:] Konstytucja Rzeczypospolitej Polskiej. Komentarz, red. L. Garlicki, M. Zubik, t. 1, LEX/el. 2016. See also J. Kostrubiec, Samorząd terytorialny, [in:] L. Dubel, J. Kostrubiec, G. Ławnikowicz, Z. Markwart, Elementy nauki o państwie i polityce, Warszawa 2011, p. 253. 
work assigned to its bodies ${ }^{2}$. Therefore, the municipal bodies cannot freely shape the status of third-party actors, and in particular by applying sovereign tools that interfere with the latter's rights, used in view of the need to ensure security and public order. Even such an important sphere as security or public order does not justify the freedom of interference, which must be based on a clear legal ground rather than vague or implied.

Pursuant to Article 16 of the Polish Constitution, the inhabitants of the units of a basic territorial division shall form a self-governing community by operation of law. The local government participates in exercising public authority. It carries out substantial part of public duties assigned under statutes on its own behalf and under its own responsibility ${ }^{3}$. In view of the above, it can be assumed that the local government, including the commune, belongs to the sphere of public authority and due to the fact that it performs tasks (including in the area of security and public order), also on its own behalf and on its own responsibility, has been equipped with an attribute of autonomy which is additionally judicially protected.

Autonomy is considered to be the basic, intrinsic feature of the local government of municipal level and concerns both the legal-public and legal-private spheres of its activity. It is also a value protected by the Polish Constitution as one of the foundations of the state's territorial system. Public-law autonomy of the commune means that it is a decentralised public authority, which operates under and within the limits set out in applicable law. Within these limits, the commune undertakes legal and actual actions, guided solely by law and its own will expressed in a statutory form by its elected bodies, or the will of members of the local community expressed in the form of a local referendum. This autonomy is subject to the supervision of state authorities in terms of legality and in the forms provided for by law. The essence of the supervision over the autonomy of local government of municipal level is the guarantee of its judicial protection ${ }^{4}$. The autonomy of the commune may not be

2 Judgement of the Voivodeship Administrative Court of 24 October 2017, III SA/Kr 397/17, LEX No. 2381414.

3 Pursuant to Article 16 (2) of the Polish Constitution, local government performs the part of public tasks conferred on it under statutes. This provision contains a basic guarantee of systemic and organisational autonomy of local government units. The basic condition for restricting this autonomy is the possibility to impose a specific duty only in a statute, and therefore only by the Sejm and the Senate. As public tasks are vested in local government under statutory provisions, therefore all permanent changes in the scope of public duties entrusted by a statute should also take place within the statutory framework (see judgement of the Constitutional Tribunal of 26 May 2015, Kp 2/13, OTK-A 2015, No. 5, item 65). Nonetheless, it should be noted that the principle of autonomy of the commune cannot be absolutised by a unilateral interpretation carried out in isolation from other political principles, in particular the principle of the unity of the state and the principle of the common good (see judgement of the Constitutional Tribunal of 18 February 2003, K 24/02, OTK-A 2003, No. 2, item 11).

4 Judgement of the Voivodeship Administrative Court of 29 March 2018, III SA/Gd 125/18, LEX No. 2473988. See also J. Kostrubiec, Kontrola administracji publicznej, [in:] Administracja 
restricted unless the law does not explicitly provide for such a possibility. However, such interference is admissible in cases of major risk to security and public order, but it can not be excessive in view of the objective to be achieved.

The commune is the basic unit of local government and performs all the duties of local government not reserved for other territorial units. This rule results from Article 164 of the Polish Constitution ${ }^{5}$. Therefore, the commune operates based on a general clause allowing for the presumption of powers for it in the matters of local government not reserved for other local government units, in particular the poviat as a local structure. Nonetheless, this clause neither does it allow the commune bodies to create new duties not resulting from a statute, nor to waive the tasks already being performed. This presumption concerns the tasks set out in a statute, but without explicitly defining the subjective competence.

The legislature defines the commune as a local government community composed, by virtue of law, of residents of the commune and the relevant territory ${ }^{6}$. The membership in a commune arises by the mere operation of law due to the fact of residing in the area of this unit, and is valid as long as the person concerned resides there?

publiczna i prawo administracyjne w zarysie, red. M. Karpiuk, J. Kowalski, Warszawa-Poznań 2013, pp. 332-333.

5 See also M. Karpiuk, J. Kostrubiec, Rechtsstatus der territorialen Selbstverwaltung in Polen, Olsztyn 2017, p. 19. Article 164 of the Polish Constitution has set out the principle of the basic character of the commune, and also supplemented and reinforced it with provisions that express the presumption of competence of the commune in all matters of local government that have not been reserved for other units of local government. See M. Masternak-Kubiak, [in:] Konstytucja Rzeczypospolitej Polskiej. Komentarz, red. M. Haczkowska, LEX/el. 2014.

6 Article 1 of the Act of 8 March 1990 on Municipal Government (consolidated text Journal of Laws 2018, item 994 as amended), hereinafter: AMG. This provision is more a portent for a future legal content than a full-fledged and precise normative regulation. See W. Kisiel, [in:] Ustawa o samorzadzie gminnym. Komentarz, red. P. Chmielnicki, LEX/el. 2013. The local government may be defined as an entity separate from the state and constituting a form of decentralisation, which comprises, by virtue of the law, the community of residents in the relevant territory, and characterised by administrative powers with judicially protected autonomy, fulfilling in its own name and on his own responsibility public tasks. See M. Karpiuk, Samorzad terytorialny a państwo. Prawne instrumenty nadzoru nad samorzadem gminnym, Lublin 2008, p. 58. The local community is composed of all the inhabitants who reside in certain units of territorial division of the country, thus comprising not only Polish nationals, but also foreigners. This is a community created by virtue of the law itself and therefore constitutes a compulsory union of citizens. A natural person may not refuse being a member of the local government and any organ of the local government may not deprive anyone of this membership. See W. Skrzydło, Konstytucja Rzeczypospolitej Polskiej. Komentarz, LEX/el. 2013.

7 Judgement of the Voivodeship Administrative Court of 3 April 2014, II SA/Go 210/14, LEX No. 1454933. 


\section{NATURE OF SECURITY AND PUBLIC ORDER}

Security and public order have not yet been defined in a statutory manner. These concepts are devised by the scholarly opinion and case law. However, the legislature often determines when security is to be protected and public order is to be asserted, without defining what is to be understood by these concepts though, and leaving these issues to law-applying bodies and courts.

The problem with the normative approach to security and public order stems mainly from the fact that it is about categories that are difficult to define, albeit intuitively recognisable and understandable. The additional difficulty is that security and public order are treated in the language of legal acts and in the jargon of legal professionals as both homogeneous and complex categories. In the first case, the legislature or legal scholars most often adopt the formula "security and public order", or more spacious one "security or public order". If the complex approach is adopted, separate categories of "(public) security" and "public order" are distinguished ${ }^{8}$.

Security is directly related to the lack of threats and the undisturbed functioning of the State, thus with ensuring appropriate conditions for the proper development of both the state institutions and social institutions, as well as society as a whole, including individual groups and individuals within.

Security is a very important area, both for the state as a public institution, and for society or for individual members thereof, and hence it should be perceived in terms of the common good. The common good constitutes the basis for public governance and democratic rule of law, thus the objective to be met by public authorities ${ }^{9}$. The common good is not a one-dimensional category, so it is not easy to define, but this does not allow public entities to get rid of the responsibility for ignoring it in their policies ${ }^{10}$.

8 M. Karpiuk, K. Prokop, P. Sobczyk, Ograniczenie korzystania z wolności i praw człowieka i obywatela ze względu na bezpieczeństwo państwa i porzadek publiczny, Siedlce 2017, pp. 9-10.

9 Cf. J. Kostrubiec, Zasada republikańskiej formy państwa, [in:] M. Bożek, M. Karpiuk, J. Kostrubiec, K. Walczuk, Zasady ustroju politycznego państwa, Poznań 2012, pp. 83-84.

10 M. Czuryk, Bezpieczeństwo jako dobro wspólne, ,Zeszyty Naukowe KUL” 2018, nr 3, p. 15. Regarding matters of security, cf. also M. Karpiuk, Wolność sumienia i wyznania a przestępstwa przeciwko tym wolnościom, [in:] Wolność sumienia i religii a bezpieczeństwo i porzadek publiczny, red. J. Nikołajew, P. Sobczyk, K. Walczuk, Warszawa 2017, pp. 49-53; M. Czuryk, K. Dunaj, M. Karpiuk, K. Prokop, Bezpieczeństwo państwa. Zagadnienia prawne i administracyjne, Olsztyn 2016, pp. 17-19; M. Karpiuk, Prawne podstawy bezpieczeństwa, [in:] Podstawowe kategorie bezpieczeństwa narodowego, red. A. Żukowski, M. Hartliński, W.T. Modzelewski, J. Więcławski, Olsztyn 2015, pp. 64-70; M. Bożek, M. Karpiuk, J. Kostrubiec, K. Walczuk, op. cit., pp. 67-68; M. Karpiuk, Bezpieczeństwo jako instytucja konstytucyjna. Zarys problematyki, [in:] Wybrane problemy bezpieczeństwa globalnego po zimnej wojnie, red. W. Gizicki, Lublin 2015, pp. 11-19; M. Czuryk, Właściwość Rady Ministrów oraz Prezesa Rady Ministrów w zakresie obronności, bezpieczeństwa i porządku publicznego, Olsztyn 2017, 
Public order concerns a specific order in a state whose elements must be mutually harmonised. The primary indicator of this will be a proper harmonisation of all segments within such an order to make up a structured whole, thus ensuring respect for socially accepted and legally protected interests. This sphere should be shaped in line with the legal patterns that are readable by the addressee and, therefore, any breach of public order will be considered, as a rule, a breach of the law.

\section{COMPETENCE OF THE COMMUNE IN THE AREA OF SECURITY AND PUBLIC ORDER}

To meet the collective needs of the community is one of the commune's own duties, and this duty covers in particular public order and citizens' safety, as well as fire and flood protection. This competence results from Article 7 (1) (14) AMG. The commune has no legal option to undertake actions that go beyond the local scope and which do not consist in meeting the collective needs of the community. In particular, however, the commune's own tasks include, i.a., the matters of public order in the commune, and the primary (basic) element of public order in the state, so including the commune, is the lawful operation of public authorities, and only then the compliance with the law by individuals ${ }^{11}$.

Article 7 (1) AMG in conjunction with Article 9 (4) AMG is a general competence provision which defines the scope of the commune's responsibilities in the performance of public utility tasks aimed at meeting the collective needs of

pp. 9; M. Karpiuk, Zadania i kompetencje zespolonej administracji rządowej w sferze bezpieczeństwa narodowego Rzeczypospolitej Polskiej. Aspekty materialne i formalne, Warszawa 2013, pp. 77-89; Aspekty prawne bezpieczeństwa narodowego RP. Część ogólna, red. W. Kitler, M. Czuryk, M. Karpiuk, Warszawa 2013, pp. 11-45; M. Karpiuk, Konstytucyjna właściwość Sejmu w zakresie bezpieczeństwa państwa, „Studia Iuridica Lublinensia” 2017, nr 4, DOI: http://dx.doi.org/10.17951/sil.2017.26.4.9, p. 10; M. Czuryk, K. Drabik, A. Pieczywok, Bezpieczeństwo człowieka w procesie zmian społecznych, kulturowych i edukacyjnych, Olsztyn 2018, p. 7; M. Karpiuk, Ograniczenie wolności uzewnętrzniania wyznania ze względu na bezpieczeństwo państwa i porzadek publiczny, „Przegląd Prawa Wyznaniowego" 2017, t. 9, pp. 10-17; M. Karpiuk, N. Szczęch, Bezpieczeństwo narodowe i międzynarodowe, Olsztyn 2017, pp. 13-40; M. Czuryk, Prawne podstawy bezpieczeństwa narodowego, [in:] Podstawy bezpieczeństwa wspótczesnego państwa (podmiotu). Implikacje, red. J. Pawłowski, Warszawa 2015, pp. 533-568; M. Karpiuk, Miejsce samorzadu terytorialnego w przestrzeni bezpieczeństwa narodowego, Warszawa 2014, pp. 28-34; idem, Prezydent Rzeczypospolitej Polskiej jako organ stojacy na straży bezpieczeństwa państwa, „Zeszyty Naukowe AON” 2009, nr 3, pp. 389-390; J. Kostrubiec, Zadania i kompetencje samorząu terytorialnego w czasie stanów nadzwyczajnych, [in:] Zadania i kompetencje samorzadu terytorialnego..., pp. 105-106; M. Karpiuk, Ubezpieczenie spoleczne rolników jako element bezpieczeństwa społecznego. Aspekty prawne, „Humanum. Międzynarodowe Studia Społeczno-Humanistyczne" 2018, nr 2, pp. 67-70.

11 Judgement of the Supreme Administrative Court of 25 April 2017, I OSK 186/17, LEX No. 2298992. 
the community. These provisions themselves do not create specific rights, but still constitute a directive which must be taken into account when the commune performs its tasks. There is no doubt that Article 7 (1) AMG cannot constitute an independent basis for issuing specific legislative acts. Such powers must result from separate statutory provisions which authorize a municipal body to undertake specific activities aimed at the performance of duties of the commune ${ }^{12}$.

At the level of commune, the legislature has introduced obligations in the field of crisis management, which according to the definition should be understood as an activity of public administration bodies forming an element of managing national security, involving the prevention of crisis situations, preparation to take control over them through planned actions, response in case of crisis situations, remedying their effects, as well as restoring critical resources and infrastructure ${ }^{13}$.

The body competent for crisis management in the commune is its executive body - either the commune head (wójt), mayor (burmistrz) or president of the city (prezydent miasta). These tasks in matters of crisis management include: 1) the management of the monitoring, planning, response to and remedying the consequences of threats in the commune area; 2) the performance of tasks in the field of civilian planning, including a) implementation of recommendations for the municipal crisis management plan, and b) drawing up and submission of the communal crisis management plan to the county head (starost) for approval; 3) the management, organising, and conducting training, drills and exercises in the field of crisis management; 4) the implementation of projects arising from the operational plan of the functioning of communes and municipalities; 5) the preventing, counteracting and remedying of the effects of terrorist events; 6) the cooperation with the head of the Internal Security Agency (Agencja Bezpieczeństwa Wewnętrznego, ABW) in counteracting, prevention and remedying of effects of terrorist events; 7) the organisation and implementation of responsibilities in the field of critical infrastructure protection. This competence results from Article 19 (1) and (2) ACM. The legislature adopted the concept of a single-person body equipped with attributes of authority exercised in the area of crisis management, without depriving the commune council of its powers in this respect, but these powers vested in the commune council are significantly limited in comparison to the executive body of this local government unit ${ }^{14}$. The fact that executive

12 Judgement of the Supreme Administrative Court of 10 February 2015, I OSK 2343/14, LEX No. 1753339.

13 Article 2 of the Act of 26 April 2007 on Crisis Management (consolidated text Journal of Laws 2018, item 1401 as amended), hereinafter: ACM. Crisis management involves measures appropriate to particular developments that arose out of a threat; it is both of a preventive and organisational nature. See judgement of the Voivodeship Administrative Court of 28 November 2012, I SA/Gd 1171/12, LEX No. 1247413.

14 M. Czuryk, K. Dunaj, M. Karpiuk, K. Prokop, Prawo zarządzania kryzysowego. Zarys systemu, Olsztyn 2016, p. 89. 
powers have been vested in a single-person body allows for faster decision-making than in the case of collective bodies, which is of paramount importance in the area of security and public order. The dynamics of threats and the resulting consequences do not allow for a delay, not only in view of the costs of restoring normal functioning of public institutions in the commune, but also because of damage to property and issues related to the threat to human health and life.

The legislature decided to systematize crisis management responsibilities of the executive body of the commune, indicating that the body shall perform them with the assistance of a specialist organisational unit of the commune (municipal) office, competent for these matters ${ }^{15}$. The performance of crisis management tasks by the head of the commune (or mayor, or president of the city) will also be supported by the municipal crisis management team.

The catalogue of crisis management tasks performed by the commune's executive body was expanded by the legislature in Article 20 ACM. The commune head, mayor or president of the city fulfils the following tasks in the commune (municipality): 1) the 24-hour alerting of members of the municipal crisis management team, and in crisis situations a 24-hour duty service to ensure the flow of information and documenting the activities being carried out; 2) cooperation with the crisis management centres of public administration bodies; 3 ) supervision of the functioning of the system of detection and alerting and the system of early warning of the population; 4) cooperation with the entities that provide environmental monitoring; 5) cooperation with rescue, search and humanitarian operation providers; 6) implementation of permanent duty service tasks for the purpose of improving the defence readiness of the state. In order to carry out the above tasks, the commune head, mayor or president of the city may establish commune (municipal) crisis management centres. They are not obliged to establish another auxiliary body, this is only within their scope of rights. If they consider that, due to the effectiveness of the fulfilment of tasks under Article $20 \mathrm{ACM}$, it will be necessary to establish a municipal crisis management centre, the commune head, mayor or president of the city may make such a decision single-handedly. They must, however, take into account the reasonableness of such a decision, the costs of operation of such an entity and the resources of the local budget.

Security issues are also crucial during states of emergency ${ }^{16}$, but the commune has been assigned the widest possible tasks in case of declaring a state of natural disaster, and the operations during a state of emergency in the region, aimed at restoring the normal functioning of public structures, are to be carried out by the

15 M. Karpiuk, Terenowe organy administracji publicznej właściwe w sprawach zarzadzania kryzysowego, „Annales UMCS sectio G (Ius)” 2014, nr 1, DOI: http://dx.doi.org/10.17951/g.2014.61.1.75, p. 83.

16 Cf. also idem, Normatywne uwarunkowania stanu wojennego i wyjątkowego, „Studia Prawnicze i Administracyjne" 2015, nr 3, pp. 3-8. 
voivodeship governor (wojewoda) who is in charge ${ }^{17}$. The same is with martial law. However, the commune authorities must manifest sufficient effectiveness in the performance of public tasks or in the implementation of the measures resulting from the rules on the declaration of martial law. Sufficient effectiveness must also be a characteristic of the activities of commune authorities during a state of emergency.

During the state of natural disaster, the activities carried out to prevent or remedy the effects of a natural disaster are headed by the commune head (mayor, president of the city) if the state of a natural disaster was declared only for the area of the commune (poviat, city) ${ }^{18}$. The legislature's intention behind adopting the principle of single-handed management during the action to remedy the consequences of a natural disaster is to ensure that the rescue action is carried out quickly and efficiently. In the event of a man-caused disaster or natural disaster, many authorities and institutions are involved in the rescue action, so it is important to harmonise their activities. However, these entities bear the main responsibility for the conduct of the rescue operation ${ }^{19}$.

As regards the managing of activities carried out in the area of the commune aimed at preventing or remedying the effects of a natural disaster, the commune head (mayor, president of the city) may issue binding instructions to the bodies of the auxiliary units, the heads of the organisational units established by the commune, the heads of fire-fighting units operating in the area of the commune and the heads of the organisational units temporarily delegated by competent authorities at his disposal and directed to perform tasks in the area of the commune. Those powers are conferred under Article 9 (2) ASND ${ }^{20}$. The powers to issue binding instructions allow the commune's executive body to better prevent or remedy the effects of a natural disaster once these occur.

As far as it is not regulated in separate statutes or other provisions of the commonly applicable law, the municipal council may issue public order provisions

17 J. Kostrubiec, Status of a Voivodship Governor as an Authority Responsible for the Matters of Security and Public Order, „Barometr Regionalny. Analizy i Prognozy” 2018, nr 5, p. 39.

18 Article 8 of the Act of 18 April 2002 on State of Natural Disaster (consolidated text Journal of Laws 2017, item 1897), hereinafter: ASND. See also M. Karpiuk, Zadania i kompetencje samorzadu terytorialnego..., p. 99.

19 P. Ruczkowski, Stan klęski żywiołowej. Komentarz, LEX/el. 2012.

20 See also M. Czuryk, Zadania organów jednostek samorządu terytorialnego $w$ stanie klęski zywiołowej, „Zeszyty Naukowe AON” 2009, nr 3, p. 408. The executive body of the commune, in managing the operations to prevent or remedy the effects of a natural disaster, shall be assisted by the entities which operate on the territory of that commune. See M. Karpiuk, Ksztattowanie sie instytucji stanów nadzwyczajnych w Polsce, Warszawa 2013, p. 151. The organisational links at municipal level allow the commune head (mayor or president of the city) to exercise the authority over the heads of the municipal organisational units. See idem, Zasady dziatania samorzadu lokalnego w czasie stanu klęski żywiołowej, „Annales UMCS sectio G (Ius)” 2014, nr 2, DOI: http://dx.doi. org/10.17951/g.2014.61.2.51, p. 55. 
where this is necessary to protect the life or health of citizens and to ensure the order, peace and public security. Therefore, according to Article 40 (3) AMG, order and security are the reasons for issuing regulatory provisions. However, that provision cannot be interpreted in an extending way ${ }^{21}$. They must be issued in special circumstances where there is no other way of providing protection against threats, and one of these circumstances is the need to ensure security and order.

As a rule, local legislation is to be enacted by a municipal council in the form of a resolution, nevertheless Article $41 \mathrm{AMG}$ provides for an exception to this rule. In the event of an urgent matter, public order provisions may be issued by the executive body of the commune in the form of a decision to be approved by the local legislature at the nearest session of the municipal council. It expires in the event of refusal of approval or failure to submit for approval at the nearest session of the municipal council. If the decision has not been submitted for approval or has been refused the approval, the municipal council shall determine the date of its expiry ${ }^{22}$. The legislator imposes on the commune head (mayor, president of the city) an obligation to send the public order provisions to the executive bodies of neighbouring communes and the starost of the poviat in which the commune is located, the day following the date of issuance thereof. Enabling a single-person body to shape the local space by means of public order provisions for reasons of security and public order is an appropriate solution, not only allowing the authorities to respond adequately to a threat, but also to quickly remedy the effects of the threat (if resources of the commune allow this).

Those public order provisions which are issued solely on the basis of general statutory authorisations contained in constitutional laws form a separate type of local legislation. They are characterised by their specific nature and intended purpose: they are to be a means of preventing the suddenly emerging threats to legally protected interests. Acts of local legislation, as opposed to acts that implement central legislation, are not issued for the implementation of legal and substantive regulations defined in statutes, but to regulate a certain sphere of social relations which has not been addressed by the central legislature, whose limits are only determined by the subject of regulation. Therefore, this regards regulation of particular local situations of an extraordinary nature which are not covered by the nation-wide regulation ${ }^{23}$.

${ }^{21}$ Idem, Przepisy porzadkowe jako szczególny rodzaj prawa miejscowego, „Studia Iuridica Lublinensia” 2015, nr 4, DOI: http://dx.doi.org/10.17951/sil.2015.24.4.21, p. 29.

22 For more about public order provisions, see M. Czuryk, Stanowienie aktów prawa miejscowego przez organy samorządu terytorialnego szczebla lokalnego i regionalnego, [in:] Akty normatywne i administracyjne, red. M. Karpiuk, Warszawa 2009, pp. 130-137; M. Karpiuk, Akty prawa miejscowego organów samorządu terytorialnego, [in:] M. Karpiuk, J. Kostrubiec, M. Paździor, K. Popik-Chorąży, K. Sikora, Legislacja administracyjna, Warszawa 2013, p. 114.

23 Judgement of the Voivodeship Administrative Court of 29 November 2017, II SA/Ke 588/17, LEX No. 2411671. 


\section{REFERENCES}

Act of 8 March 1990 on Municipal Government (consolidated text Journal of Laws 2018, item 994 as amended).

Act of 18 April 2002 on State of Natural Disaster (consolidated text Journal of Laws 2017, item 1897).

Act of 26 April 2007 on Crisis Management (consolidated text Journal of Laws 2018, item 1401 as amended).

Aspekty prawne bezpieczeństwa narodowego RP. Część ogólna, red. W. Kitler, M. Czuryk, M. Karpiuk, Warszawa 2013.

Bożek M., Karpiuk M., Kostrubiec J., Walczuk K., Zasady ustroju politycznego państwa, Poznań 2012.

Constitution of the Republic of Poland of 2 April 1997 (Journal of Laws No. 78, item 483 as amended).

Czuryk M., Bezpieczeństwo jako dobro wspólne, „Zeszyty Naukowe KUL”2018, nr 3.

Czuryk M., Prawne podstawy bezpieczeństwa narodowego, [in:] Podstawy bezpieczeństwa wspótczesnego państwa (podmiotu). Implikacje, red. J. Pawłowski, Warszawa 2015.

Czuryk M., Stanowienie aktów prawa miejscowego przez organy samorzadu terytorialnego szczebla lokalnego i regionalnego, [in:] Akty normatywne i administracyjne, red. M. Karpiuk, Warszawa 2009.

Czuryk M., Właściwość Rady Ministrów oraz Prezesa Rady Ministrów w zakresie obronności, bezpieczeństwa i porzadku publicznego, Olsztyn 2017.

Czuryk M., Zadania organów jednostek samorzadu terytorialnego w stanie klęski żywiołowej, „Zeszyty Naukowe AON" 2009, nr 3.

Czuryk M., Drabik K., Pieczywok A., Bezpieczeństwo człowieka w procesie zmian społecznych, kulturowych i edukacyjnych, Olsztyn 2018.

Czuryk M., Dunaj K., Karpiuk M., Prokop K., Bezpieczeństwo państwa. Zagadnienia prawne i administracyjne, Olsztyn 2016.

Czuryk M., Dunaj K., Karpiuk M., Prokop K., Prawo zarządzania kryzysowego. Zarys systemu, Olsztyn 2016.

Judgement of the Constitutional Tribunal of 18 February 2003, K 24/02, OTK-A 2003, No. 2, item 11. Judgement of the Constitutional Tribunal of 26 May 2015, Kp 2/13, OTK-A 2015, No. 5, item 65.

Judgement of the Supreme Administrative Court of 10 February 2015, I OSK 2343/14, LEX No. 1753339.

Judgement of the Supreme Administrative Court of 25 April 2017, I OSK 186/17, LEX No. 2298992.

Judgement of the Voivodeship Administrative Court of 28 November 2012, I SA/Gd 1171/12, LEX No. 1247413.

Judgement of the Voivodeship Administrative Court of 3 April 2014, II SA/Go 210/14, LEX No. 1454933.

Judgement of the Voivodeship Administrative Court of 24 October 2017, III SA/Kr 397/17, LEX No. 2381414.

Judgement of the Voivodeship Administrative Court of 29 November 2017, II SA/Ke 588/17, LEX No. 2411671.

Judgement of the Voivodeship Administrative Court of 29 March 2018, III SA/Gd 125/18, LEX No. 2473988.

Karpiuk M., Akty prawa miejscowego organów samorzadu terytorialnego, [in:] M. Karpiuk, J. Kostrubiec, M. Paździor, K. Popik-Chorąży, K. Sikora, Legislacja administracyjna, Warszawa 2013.

Karpiuk M., Bezpieczeństwo jako instytucja konstytucyjna. Zarys problematyki, [in:] Wybrane problemy bezpieczeństwa globalnego po zimnej wojnie, red. W. Gizicki, Lublin 2015.

Karpiuk M., Konstytucyjna właściwość Sejmu w zakresie bezpieczeństwa państwa, „Studia Iuridica Lublinensia” 2017, nr 4, DOI: http://dx.doi.org/10.17951/sil.2017.26.4.9.

Karpiuk M., Kształtowanie się instytucji stanów nadzwyczajnych w Polsce, Warszawa 2013. 
Karpiuk M., Miejsce samorządu terytorialnego w przestrzeni bezpieczeństwa narodowego, Warszawa 2014.

Karpiuk M., Normatywne uwarunkowania stanu wojennego i wyjątkowego, „Studia Prawnicze i Administracyjne" 2015, nr 3.

Karpiuk M., Ograniczenie wolności uzewnętrzniania wyznania ze względu na bezpieczeństwo państwa i porzadek publiczny, „Przegląd Prawa Wyznaniowego” 2017, t. 9.

Karpiuk M., Prawne podstawy bezpieczeństwa, [in:] Podstawowe kategorie bezpieczeństwa narodowego, red. A. Żukowski, M. Hartliński, W.T. Modzelewski, J. Więcławski, Olsztyn 2015.

Karpiuk M., Prezydent Rzeczypospolitej Polskiej jako organ stojący na straży bezpieczeństwa państwa, „Zeszyty Naukowe AON” 2009, nr 3.

Karpiuk M., Przepisy porzadkowe jako szczególny rodzaj prawa miejscowego, „Studia Iuridica Lublinensia” 2015, nr 4, DOI: http://dx.doi.org/10.17951/sil.2015.24.4.21.

Karpiuk M., Samorząd terytorialny a państwo. Prawne instrumenty nadzoru nad samorzadem gminnym, Lublin 2008.

Karpiuk M., Terenowe organy administracji publicznej właściwe w sprawach zarzadzania kryzysowego, „Annales UMCS sectio G (Ius)” 2014, nr 1, DOI: http://dx.doi.org/10.17951/g.2014.61.1.75.

Karpiuk M., Ubezpieczenie społeczne rolników jako element bezpieczeństwa społecznego. Aspekty prawne, „Humanum. Międzynarodowe Studia Społeczno-Humanistyczne” 2018, nr 2.

Karpiuk M., Wolność sumienia i wyznania a przestęstwa przeciwko tym wolnościom, [in:] Wolność sumienia i religii a bezpieczeństwo i porządek publiczny, red. J. Nikołajew, P. Sobczyk, K. Walczuk, Warszawa 2017.

Karpiuk M., Zadania i kompetencje samorządu terytorialnego w czasie stanów nadzwyczajnych, [in:] Zadania i kompetencje samorzadu terytorialnego w zakresie porzadku publicznego i bezpieczeństwa obywateli, obronności oraz ochrony przeciwpożarowej i przeciwpowodziowej, red. M. Karpiuk, M. Mazuryk, I. Wieczorek, Łódź 2017.

Karpiuk M., Zadania i kompetencje zespolonej administracji rzadowej w sferze bezpieczeństwa narodowego Rzeczypospolitej Polskiej. Aspekty materialne i formalne, Warszawa 2013.

Karpiuk M., Zasady działania samorzadu lokalnego w czasie stanu klęski żywiołowej, „Annales UMCS sectio G (Ius)" 2014, nr 2, DOI: http://dx.doi.org/10.17951/g.2014.61.2.51.

Karpiuk M., Kostrubiec J., Rechtsstatus der territorialen Selbstverwaltung in Polen, Olsztyn 2017.

Karpiuk M., Prokop K., Sobczyk P., Ograniczenie korzystania z wolności i praw człowieka i obywatela ze względu na bezpieczeństwo państwa i porzadek publiczny, Siedlce 2017.

Karpiuk M., Szczęch N., Bezpieczeństwo narodowe i międzynarodowe, Olsztyn 2017.

Kisiel W., [in:] Ustawa o samorzadzie gminnym. Komentarz, red. P. Chmielnicki, LEX/el. 2013.

Kostrubiec J., Kontrola administracji publicznej, [in:] Administracja publiczna i prawo administracyjne w zarysie, red. M. Karpiuk, J. Kowalski, Warszawa-Poznań 2013.

Kostrubiec J., Samorząd terytorialny, [in:] L. Dubel, J. Kostrubiec, G. Ławnikowicz, Z. Markwart, Elementy nauki o państwie i polityce, Warszawa 2011.

Kostrubiec J., Status of a Voivodship Governor as an Authority Responsible for the Matters of Security and Public Order, „Barometr Regionalny. Analizy i Prognozy” 2018, nr 5.

Kostrubiec J., Zadania i kompetencje samorzadu terytorialnego $w$ zakresie administracji rezerw osobowych dla celów powszechnego obowiązu obrony, [in:] Zadania i kompetencje samorzadu terytorialnego w zakresie porzadku publicznego i bezpieczeństwa obywateli, obronności oraz ochrony przeciwpożarowej i przeciwpowodziowej, red. M. Karpiuk, M. Mazuryk, I. Wieczorek, Łódź 2017.

Kostrubiec J., Zasada republikańskiej formy państwa, [in:] M. Bożek, M. Karpiuk, J. Kostrubiec, K. Walczuk, Zasady ustroju politycznego państwa, Poznań 2012.

Masternak-Kubiak M., [in:] Konstytucja Rzeczypospolitej Polskiej. Komentarz, red. M. Haczkowska, LEX/el. 2014. 
Pobrane z czasopisma Studia Iuridica Lublinensia http://studiaiuridica.umes.pl Data: 26/04/2023 14:55:17

Position of the Local Government of Commune Level in the Space of Security...

Ruczkowski P., Stan klęski żywiołowej. Komentarz, LEX/el. 2012.

Sarnecki P., [in:] Konstytucja Rzeczypospolitej Polskiej. Komentarz, red. L. Garlicki, M. Zubik, t. 1, LEX/el. 2016.

Skrzydło W., Konstytucja Rzeczypospolitej Polskiej. Komentarz, LEX/el. 2013.

\section{STRESZCZENIE}

W artykule podjęto problematykę dotyczącą miejsca samorządu gminnego w przestrzeni bezpieczeństwa i porząaku publicznego. Gmina wykonuje zadania w tym zakresie obok innych zadań publicznych, przy czym zapewnienie bezpieczeństwa i porządku publicznego należy do zadań podstawowych, których realizacja wymaga znacznego zaangażowania, w tym znacznych nakładów finansowych. Gmina jako podstawowa jednostka samorządu terytorialnego najszybciej ma reagować na zagrożenie i za pośrednictwem posiadanych sił i środków ma je neutralizować bądź - jeżeli nie jest to możliwe - powstrzymać jego rozprzestrzenianie się. Jest to główny cel gminy, jaki ma być realizowany w powyższym obszarze wykonywania administracji publicznej.

Słowa kluczowe: gmina; bezpieczeństwo; porządek publiczny 